\title{
Larval development and shape variation of the kelpfish Myxodes viridis (Teleostei: Clinidae)
}

\author{
Francisca Zavala-Muñoz ${ }^{1}$, Mauricio F. Landaeta ${ }^{1}$, Valentina Bernal-Durán ${ }^{1}$, \\ Guillermo A. Herrera ${ }^{2}$, Donald I. Brown ${ }^{3}$ \\ ${ }^{1}$ Laboratorio de Ictioplancton (LABITI), Escuela de Biología Marina, Facultad de Ciencias del Mar y de Recursos Naturales, \\ Universidad de Valparaíso, Avenida Borgoño 16344, Reñaca, Viña del Mar, Chile. E-mail: mauricio.landaeta@uv.cl \\ ${ }^{2}$ Facultad de Ciencias, Universidad Católica de la Santísima Concepción, Concepción, Chile. \\ Unidad de Biología de la Reproducción y del Desarrollo, Instituto de Biología, Facultad de Ciencias, Universidad de \\ Valparaíso, Valparaíso, Chile.
}

\begin{abstract}
Summary: Larval development and shape ontogeny of the kelpfish Myxodes viridis (Clinidae) are described for the first time. A total of 214 individuals ranging between 3.51 and $23.09 \mathrm{~mm}$ standard length collected off central Chile were assessed employing classic and geometric morphometrics, illustration with camera lucida and a double-staining technique for cartilaginous and bone structure observation. Based on characteristics such as yolk sac presence and fin formation, six stages of larval development were differentiated: yolk sac, preflexion, flexion, early postflexion, late postflexion and juvenile. Shape changes during development are subtle and occur smoothly, being more significant in the head and preanal length, and ontogenetic allometry accounts for almost $15 \%$. Cartilage formation takes place first at the branchial arches and cranium; then hypural, haemal and neural arches are consecutively formed. Bony structure ossification occurs late in the development. Vertebral centra ossify directly, without cartilaginous matrix replacement.
\end{abstract}

Keywords: Myxodes viridis, Clinidae family; early ontogenetic development; ichthyoplankton; geometric morphometrics; classic morphometrics; osteology.

Desarrollo larval y variación de la forma de la doncellita Myxodes viridis (Teleostei: Clinidae)

Resumen: Se describe por primera vez el desarrollo larval y la ontogenia de la forma de la doncellita Myxodes viridis (Clinidae). Se utilizaron 214 individuos, que variaron entre 3.51 y $23.09 \mathrm{~mm} \mathrm{LE}$, recolectados frente a Chile central, para describir la morfometría clásica, geométrica, ilustraciones con cámara lucida y observación de estructuras cartilaginosas y óseas teñidas. Se diferenciaron 6 estados de desarrollo larvario basada en características como la presencia de saco vitelino y la formación de aletas: larva con saco vitelino, preflexión, postflexión temprana, postflexión tardía y juvenil. Los cambios de forma a través del desarrollo fueron sutiles y cambiaron levemente, siendo más significativos en la cabeza y longitud preanal y la alometría ontogenética correspondió a un $15 \%$ de los cambios de forma. La formación de cartílago ocurre primero en los arcos branquiales y el cráneo, luego se forman consecutivamente los elementos hipurales y los arcos hemales y neurales. La osificación de las estructuras ocurre tarde en el desarrollo. Los centros vertebrales se osifican directamente, sin reemplazo de la matriz cartilaginosa.

Palabras clave: Myxodes viridis; familia Clinidae; desarrollo ontogenético temprano; ictioplancton; morfometría geométrica; morfometría clásica; osteología.

Citation/Como citar este artículo: Zavala-Muñoz F., Landaeta M.L., Bernal-Durán V., Herrera G.A., Brown D.I. 2016. Larval development and shape variation of the kelpfish Myxodes viridis (Teleostei: Clinidae). Sci. Mar. 80(1): 39-49. doi: http://dx.doi.org/10.3989/scimar.04263.24C

Editor: A. Sabatés.

Received: April 27, 2015. Accepted: September 1, 2015. Published: December 11, 2015.

Copyright: (C) 2016 CSIC. This is an open-access article distributed under the Creative Commons Attribution-Non Commercial Lisence (by-nc) Spain 3.0.

\section{INTRODUCTION}

Fish larvae often go through very complex processes of metamorphosis during growth. A wide variety of developmental patterns, characterized by differential growth of different regions of the body at different sizes, are described for marine species and justified via ecomorphological hypotheses about the allocation of energy during growth (Russo et al. 2007). Certain species undergo gradual changes, whereas other species 
experience threshold effects in their ecomorphological relationships during ontogeny (Kouttouki et al. 2006, Russo et al. 2009, Frédérich et al. 2008, 2012).

In fish species with pelagic and filiform larval stages and an elongate adult body form, the ontogenetic growth intensities are not distributed uniformly across the body but in a regular pattern, constituting a smooth, continuous gradient. The gradient is characterized by a period with terminal growth centres (high intensities), corresponding to head and tail, and a continuous, Ushaped gradient between them (Fuiman 1983). In these species, the completion of the head is crucial for feeding and respiratory functions, whereas the completion of the tail is pivotal for cruising and escape reactions (Russo et al. 2009).

The suborder Blennoidei includes 6 families and over 880 benthic species (Hastings and Springer 2009), which inhabit shallow waters of tropical and temperate seas. The family Clinidae consists of relatively small fishes with a standard length (SL) of less than $300 \mathrm{~mm}$ placed in three tribes: the matritrophic (ovoviviparous) Clinini and Ophiclinini, and the oviparous Myxodini (George and Springer 1980, Stepien 1992). The sole representative of the family Clinidae in Southeastern Pacific coasts is the genus Myxodes, with three described species: Myxodes viridis Valenciennes, 1836, $M$. cristatus Valenciennes, 1836, and $M$. ornatus (Stephens and Springer 1973). Myxodes viridis ranges from Independencia Bay, Peru, to southern Chile (Pequeño et al. 1995). The adults feed mostly on crabs, whereas juveniles $(<75 \mathrm{~mm}$ SL) eat primarily harpacticoid copepods, amphipods, gastropod snails and isopods (Stepien 1990). The pelagic larvae change from omnivory to carnivory as they develop, preying mainly on nauplii and calanoid copepodites (OchoaMuñoz et al. 2013). Although there is some knowledge of the early life history of other blennoids of the region, e.g. blennoids, dactyloscopids and tripterigiids (Ciechomski 1975, Balbontín and Pérez 1979, Herrera et al. 2007), the larvae of $M$. viridis have not been described yet.

The classical distance-based morphometry (DBM) used in the first description of a larval fish development consists of a survey of measurements along the body (biometries), which are selected a priori by making assumptions about form and function. A way to understand the patterns of allometric growth and shape change is to utilize geometric morphometry techniques. Geometric morphometry deals directly with coordinates of anatomical landmarks, either in two or three dimensions, rather than with traditional distance or angle measurements (Zeldrich et al. 2004). Landmark points have been defined by Bookstein (1991) as loci that have names as well as Cartesian coordinates. Ontogenetic changes associated with growth and development, where there is a clear directionality from young to older organisms, are examples of shape changes (Klingenberg 2013), understood as the movement from a referential point towards another representing the target shape. This means that it is a vector that has a direction and a magnitude (or length; Klingenberg and Monteiro 2005).
Therefore, utilizing the larvae of the kelpfish Myxodes viridis as a model species, the ontogenetic changes of early stages of a marine fish with pelagic larval phase and benthic adult phase is described using a classical (DBM) approach and geometric morphometry techniques to quantify the shape changes. From an ecomorphological perspective, the development and shape change during early ontogeny of $M$. viridis will reflect the requirements for improving survival during the pelagic stage. Then, two plausible predictions arise: one, the head will show the largest shape change in order to increase feeding success, or two, the tail will show the greatest shape change in order to increase predator avoidance. The objective of this work is to describe the larval development and shape changes during the early ontogeny of the kelpfish Myxodes viridis using two complementary methodologies, in order to increase the taxonomic knowledge of this family in South America.

\section{MATERIALS AND METHODS}

\section{Fieldwork}

During the late austral winter and spring of 20102012, 13 dusk and nocturnal coastal surveys (1930 to $2300 \mathrm{~h}$ ) were conducted in El Quisco Bay (33⒉' $\mathrm{S}$, $71^{\circ} 43^{\prime} \mathrm{W}$ ) onboard an artisanal vessel. Plankton samples were obtained in oblique tows with a Bongo net $(60 \mathrm{~cm}$ diameter, $300 \mu \mathrm{m}$ mesh and two TSK flowmeters) performed in nearshore waters ( $<1 \mathrm{~km}$ distance from shore) for 15-20 min from a depth of $20 \mathrm{~m}$. Filtered seawater ranged from 13.1 to $437.4 \mathrm{~m}^{3}$. The plankton samples (166) were preserved in 5\% buffered (sodium borate) formalin and transferred to $96 \%$ ethanol after $12 \mathrm{~h}$.

\section{Laboratory work}

In the laboratory, all fish larvae from the plankton samples were sorted, counted and identified to the lowest taxonomic level. Larval Myxodes viridis were identified by the series method (Ahlstrom and Ball 1954, Ahlstrom et al. 1976, Neira et al. 1998). Measurements were made to the nearest $0.01 \mathrm{~mm}$ under an Olympus SZ-61 stereomicroscope using a Moticam 2500 (5.0 Mpixel) video camera connected to a PC with Moticam Image Plus 2.0 software. Measurements used here are defined by Moser (1996), and correspond to SL, head length (HL), preanal length (PAL), snout length (SnL), eye diameter (ED), and body depth (BD) (Fig. 1). Pigments refer solely to melanophores.

The illustrations were done using a stereomicroscope with a camera lucida. Drawings were done by hand and scanned for image edition with GIMP 2.6.12-1ubuntu 1.3 software.

\section{Cartilage and bone staining}

To set meristic characters and observe the ossification process during the development, a double staining technique modified from Menegola et al. (2001) and Gillis et al. (2009) was applied to eight larvae ranging from $4.69 \mathrm{~mm}$ to $23.09 \mathrm{~mm}$ SL. After re hydration in 


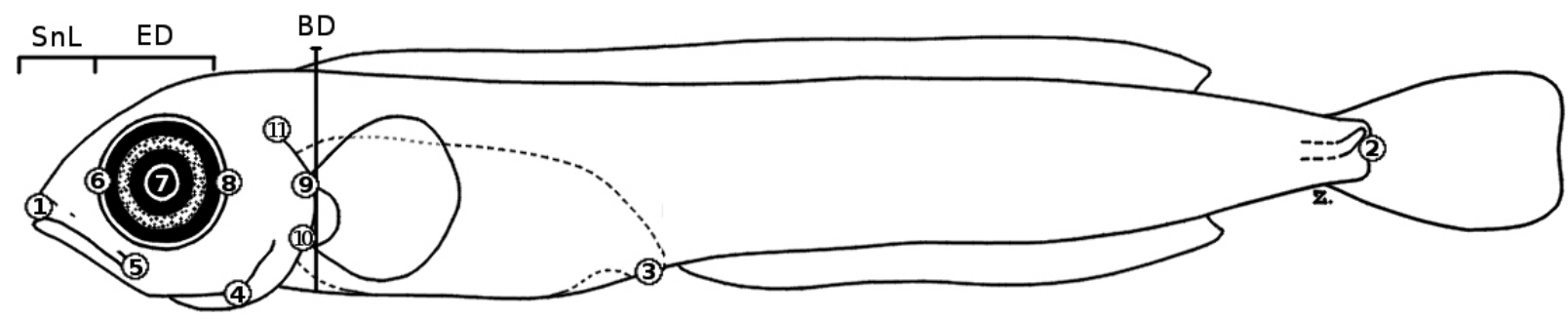

$\mathrm{HL}$

$\mathrm{PAL}$, $S L$

Fig. 1. - Measurements taken on the lateral aspect of each larvae and configuration of 13 landmarks used in the analysis of shape ontogeny of the kelpfish Myxodes viridis. Measurements: SL, standard length; PAL, preanal length; HL, head length; SnL, snout length; ED, eye diameter; BD, body depth. Landmarks: 1, snout tip; 2, posterior body extremity; 3, anus; 4, hindgut; 5, foregut loop; 6, cleithral symphysis; 7, angle of lower jaw; 8, centre of the eye; 9 hindbrain; 10, upper extreme of the eye; 11, lower extreme of the eye; 12, upper limit of the opercle; 13, anal position at the dorsal margin. Drawings by F. Zavala-Muñoz.

$70 \%$ ethanol, larvae were placed in the Alcian blueAlizarin red S acid staining solution, then washed three times in $95 \%$ ethanol and placed in the Alizarin red S basic staining solution (Menegola et al. 2001). Then, larvae were treated with graded $\mathrm{KOH} /$ glycerol series (Gillis et al. 2009) and finally stored in 100\% glycerol at room temperature.

\section{Geometric morphometrics}

Selected individuals were photographed on the left side with an Olympus SZ61 stereomicroscope attached to a camera (Motic Moticam 2500, resolution 5.0 MPixel) using Motic Image Plus 2.0 software. To carry out the geometric morphometrics, photographed larvae were divided into four groups (preflexion, flexion, postflexion and transformation). A configuration of 13 landmarks was applied to study 67 larval kelpfish (Fig. 1), ranging from 4.00 to $22.22 \mathrm{~mm} \mathrm{BL}$. In the use of landmarks it is necessary to avoid bias produced by fixative procedures, so all specimens must keep the same anatomical position. Therefore, only wellpreserved individuals with the same methodology were used for geometric morphometry. Subsequently, a database was created using the tpsUtil program (version 1.58, Rohlf 2006), and the landmarks were digitized with the tpsDig program (version 2.17, Rohlf 2006). The coordinates obtained for each individual were centred, scaled and rotated to obtain a consensus figure using the Generalized Procrustes Analysis (MorphoJ, version 1.05f, Klingenberg 2011). These new coordinates were used for further statistical comparisons. Principal component analysis (PCA) was performed to identify the main axes of shape change and the specific changes in the larval body (reflected as movements of landmarks) that explain the variability of the data. To visualilze the shape changes, warping transformation grids were applied to the drawing only, without the grid, following Klingenberg (2013). Procrustes ANOVA was carried out to assess the relative amounts of variation among individuals and of measurement error using MorphoJ. In general, allometric changes between somatic parameters are expressed by a potential equation (see Lleonart et al. 2000); however, in geometric morphometry, allometry is widely characterized by multivariate regression of shape on size (usually centroid size or log-transformed centroid size); such regressions often fit the data well and the allometric shape changes tend to affect the entire structures under study (Loy et al. 1998, Mitteroecker et al. 2004, Klingenberg and Marugán-Lobón 2013). Therefore, a regression between a regression score of each independent variable (Procrustes coordinates) and centroid size was carried out with MorphoJ (Sidlaukas et al. 2011). The allometry corresponds to the proportion of variation for which the regression accounts as a percentage of the total variation.

\section{RESULTS}

A total of 214 larvae were used for the dynamic description, ranging from 3.51 to $23.09 \mathrm{~mm}$ SL (mean \pm standard deviation; $6.91 \pm 2.85 \mathrm{~mm}$ ). Late postflexion larvae of $M$. viridis can be distinguished from those of other co-occurring Clinidae and Labrisomidae by the number of spines and soft rays in the dorsal fin (D XXIV-XXVI, 6-7), longer preanal distance, and persistent melanophores over the gut throughout the larval development.

\section{Dynamic description of larval development}

Body

The body shape of Myxodes viridis is elongated throughout the larval development (BD 10-20\% SL) (Table 1$)$. Body Depth is $10.33 \%$ SL $( \pm 1.35)$ in preflexion larvae, and slightly larger in flexion and postflexion (BD 10.5 $\pm 0.82 \%$ SL and BD $11.83 \pm 1.51 \%$ SL, respectively). Notochord flexion occurs between 6.1 $\mathrm{mm}$ and $7.6 \mathrm{~mm}$ SL. Preanal length (PAL) is moderate (between $30-50 \%$ SL) to long (between $50-70 \%$ SL) (Table 1). Preflexion larvae have a PAL of $49.62 \%$ of SL ( \pm 3.47$)$, and slightly lower in flexion and postflexion larvae (PAL 48.56 $\pm 2.9 \%$ SL and PAL 47.5 $\pm 2.22 \%$ $\mathrm{SL}$, respectively). 
Table 1. - Morphometric data (\%BL, \% of body length; \%HL, \% of head length), and meristic counts (D, dorsal fin; A, anal fin; P1, pectoral fins; P2, pelvic fins; C, caudal fin) for larvae of Myxodes viridis.

\begin{tabular}{|c|c|c|c|c|c|c|c|c|c|c|c|}
\hline Stage & $\mathrm{BL}(\mathrm{mm})$ & $\begin{array}{l}\text { Head length } \\
\quad(\% \mathrm{BL})\end{array}$ & $\begin{array}{c}\text { Preanal length } \\
(\% \mathrm{BL})\end{array}$ & $\begin{array}{c}\text { Snout length } \\
(\% \mathrm{HL})\end{array}$ & $\begin{array}{c}\text { Eye diameter } \\
(\% \mathrm{HL})\end{array}$ & $\begin{array}{l}\text { Body depth } \\
(\% \mathrm{BL})\end{array}$ & $\mathrm{D}$ & A & P1 & $\mathrm{P} 2$ & $\mathrm{C}$ \\
\hline Preflexion & 3.51 & 16.81 & 48.72 & 16.95 & 45.76 & 13.96 & - & - & - & - & - \\
\hline Preflexion & 4.22 & 16.59 & 49.76 & 11.43 & 44.29 & 10.66 & - & - & - & - & - \\
\hline Preflexion & 4.76 & 15.34 & 49.16 & 12.33 & 42.47 & 11.13 & - & - & - & - & - \\
\hline Preflexion & 4.93 & 16.63 & 49.70 & 17.07 & 39.02 & 10.95 & - & - & - & - & - \\
\hline Preflexion & 5.00 & 15.20 & 48.40 & 14.47 & 42.11 & 10.60 & - & - & - & - & - \\
\hline Preflexion & 5.23 & 16.44 & 50.48 & 25.58 & 40.70 & 11.66 & - & - & - & - & - \\
\hline Flexion & 5.35 & 14.77 & 49.16 & 16.46 & 40.51 & 9.53 & - & - & - & - & - \\
\hline Flexion & 5.60 & 14.46 & 46.61 & 27.16 & 39.51 & 10.71 & - & - & - & - & - \\
\hline Flexion & 5.99 & 18.36 & 50.75 & 20.00 & 30.91 & 10.68 & - & - & - & - & - \\
\hline Flexion & 6.16 & 14.77 & 50.00 & 16.48 & 35.16 & 9.90 & - & - & - & - & - \\
\hline Flexion & 6.36 & 16.35 & 50.63 & 22.12 & 33.65 & 10.38 & - & - & - & - & - \\
\hline Flexion & 6.55 & 19.69 & 50.84 & 20.93 & 23.26 & 11.30 & - & - & - & - & - \\
\hline Postflexion & 6.91 & 18.81 & 48.91 & 21.54 & 27.69 & 10.13 & - & - & - & - & - \\
\hline Postflexion & 7.16 & 18.99 & 48.74 & 25.00 & 29.41 & 11.45 & - & - & - & - & - \\
\hline Postflexion & 7.42 & 17.65 & 49.06 & 23.66 & 32.82 & 12.40 & - & - & - & - & - \\
\hline Postflexion & 7.61 & 17.61 & 47.96 & 26.87 & 30.60 & 13.01 & - & - & - & - & 12 \\
\hline Postflexion & 7.96 & 18.97 & 47.11 & 26.49 & 27.15 & 11.56 & - & - & - & - & 13 \\
\hline Postflexion & 8.13 & 21.76 & 49.89 & 24.24 & 26.77 & 12.86 & - & - & - & - & 13 \\
\hline Postflexion & 8.91 & 19.90 & 42.31 & 20.82 & 26.39 & 13.91 & - & - & - & - & 12 \\
\hline Juvenile & 18.73 & 23.60 & 42.77 & 21.04 & 18.78 & 12.44 & 6 & II, 25 & - & - & 13 \\
\hline Juvenile & 23.09 & 23.52 & 43.40 & 21.73 & 24.31 & 17.45 & XXXV, 6 & II, 25 & 11 & I, 3 & 13 \\
\hline
\end{tabular}

\section{Internal organs}

The foregut is coiled anteriorly. The midgut has striations from the end of the coil to the constriction prior to the rectum. The gas bladder is located over the midgut; it was present in all individuals and there were no signs of change in its size or position throughout the development. In juveniles, it is difficult to observe because it is covered by myomeres (Fig. 2).

\section{Head}

In preflexion larvae $\mathrm{HL}$ is $17.02 \% \mathrm{SL}( \pm 1.87 \%)$, qualifying as small. In flexion larvae HL is smaller, 16.84 $( \pm 1.69 \% \mathrm{SL})$, but increases considerably in postflexion (HL 19.74 $\pm 2.19 \%$ SL), and over $20 \%$ SL in juveniles. $\mathrm{SnL}$, as a proportion of HL, is very small in preflexion larvae (SnL 14.87 $\pm 4.79 \%$ HL) but increases considerably in flexion (SnL 19.38 $\pm 5.12 \% \mathrm{HL}$ ) and postflexion (SnL 23.5 $\pm 3.16 \%$ HL). This is due to a change in the shape of the head, from rounded with a low mouth in yolk sac, preflexion and flexion larvae to pointed with a mouth placed higher and in a terminal position.

$\mathrm{ED}$ is $37.41 \%( \pm 5.16 \%)$ of HL in preflexion larvae, $33.44( \pm 4.66 \%)$ in flexion and $26.88( \pm 3.00 \%)$ in postflexion. All studied larvae had pigmented eyes. Nostrils are formed in individuals larger than $18 \mathrm{~mm}$ SL. Single supraocular cirri were observed only in juveniles (Fig. 2F).

\section{Fin formation sequence}

Pectoral fins can be distinguished in larvae from 5 mm SL (Fig. 2B) as a simple bud and a lamina. Formation of pectoral fin rays occurs late in the development, as they were observed only in larvae larger than $14 \mathrm{~mm}$ SL. Notochord flexion and caudal fin formation were observed in individuals larger than $6.1 \mathrm{~mm}$ SL (Fig. 2C). The caudal fin is completely formed after $7.6 \mathrm{~mm}$ SL.
Dorsal and anal fins develop almost simultaneously in advanced postflexion stages, after $8.5 \mathrm{~mm}$ SL. The first pterygiophores form at the base of the posterior part of both fins. All rays (6-7 in the posterior part of the dorsal fin and 24-25 in the anal fin) and spines (XXXIV-XXXVI dorsal, II anal) appear in individuals larger than $13 \mathrm{~mm}$ SL. No signs of pelvic fin formation were apparent in larvae smaller than $16 \mathrm{~mm}$ SL.

\section{Pigmentation}

The larvae of $M$. viridis show little pigmentation throughout the development. Early preflexion larvae usually have few small ventral melanophores, one or two (rarely three or none) in the midgut, one larger and round under the foregut (anterior to the coil), and one small and branched in the constriction anterior to the rectum. Under the ventral margin of the tail, between the anus and the caudal peduncle, there is a series of four to six small round melanophores evenly spaced at five to six myomeres; these increase in number during development and reach one melanophore at the base of each pterygiophore in juveniles. In the middle of the tail of early larvae, even in yolk sac stages, a distinctive, large and branched melanophore forms on the ventral margin, with branches that extend over the sides of the body and in the fin fold. This melanophore decreases in size during development, and in larvae larger than $10 \mathrm{~mm}$ SL it becomes indistinguishable from the rest of the ventral series (Fig. 2F). This melanophore is similar to the one observed in the development of the labrisomid Labrisomus xanthi (Watson 1996).

A large dendritic melanophore that develops dorsally on the gas bladder can be observed in larvae smaller than $9 \mathrm{~mm}$ SL as it becomes embedded during development in larger larvae. A single, usually enlongate melanophore develops on each side of the isthmus during early preflexion. 
A

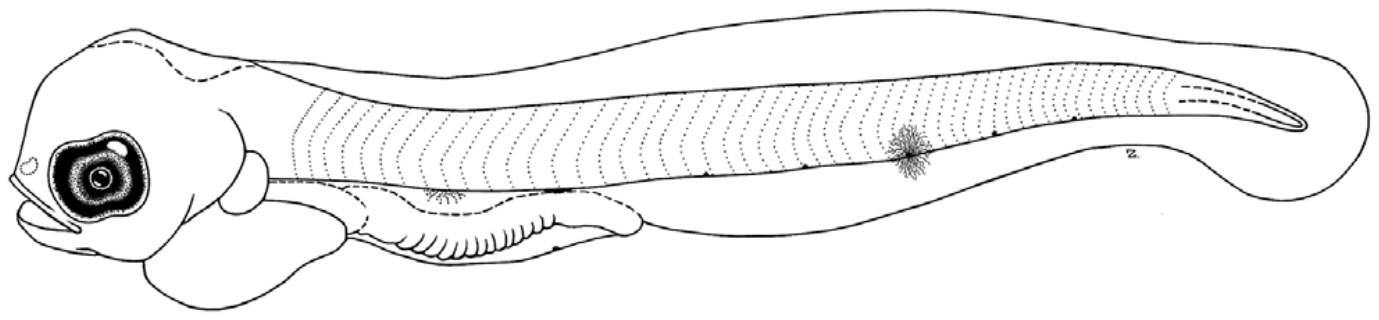

B

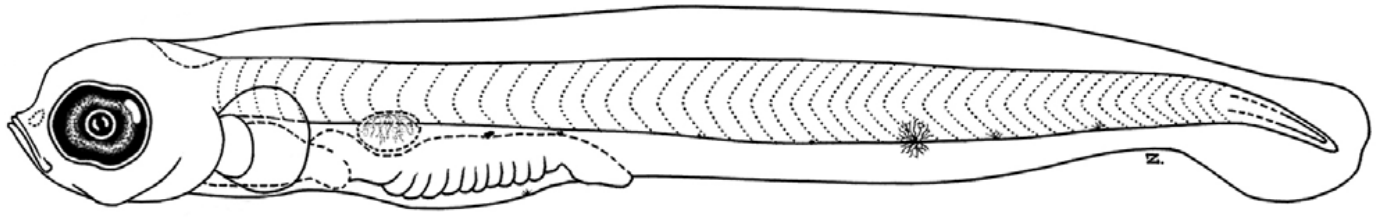

C
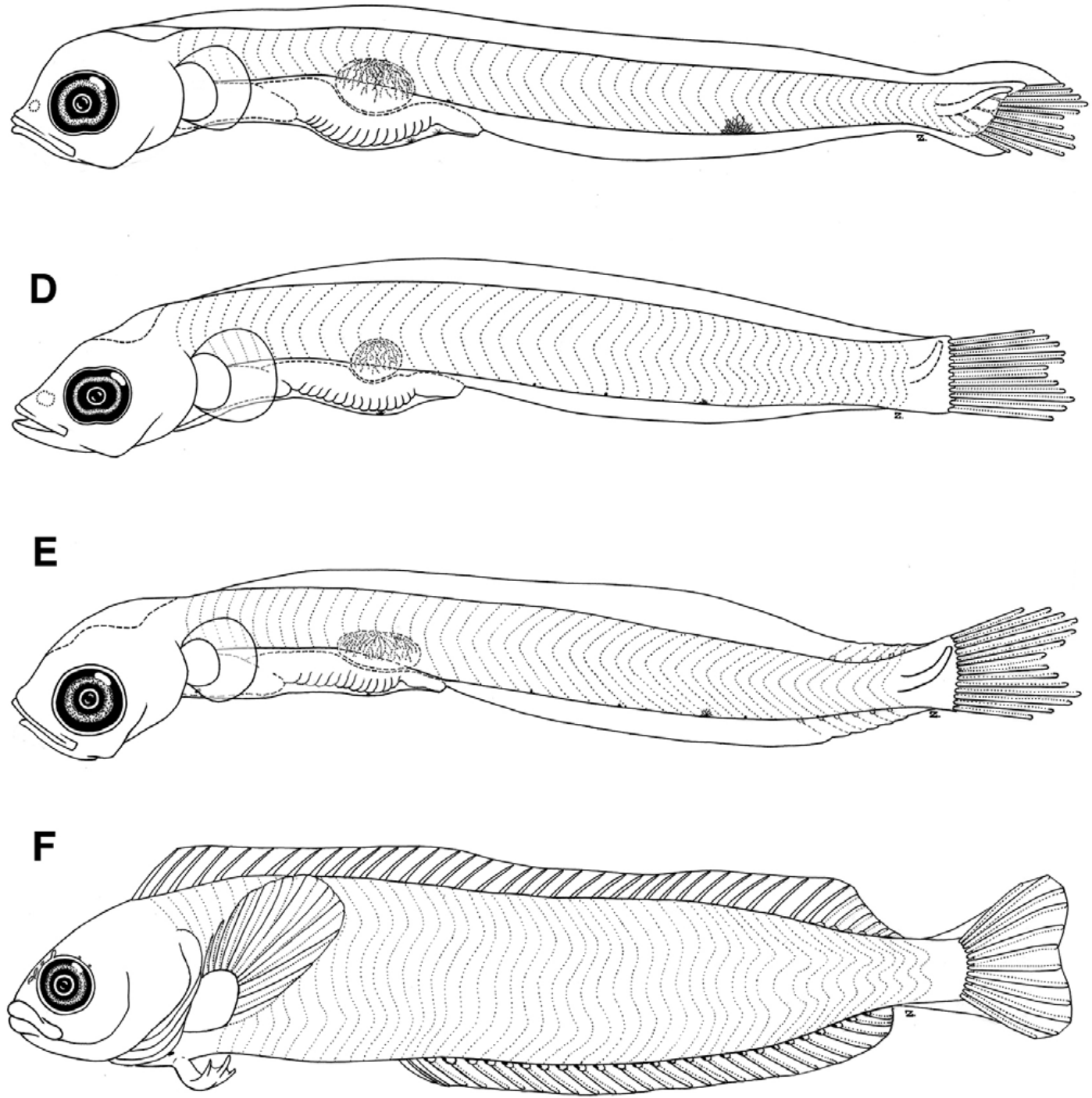

Fig. 2. - Larvae of kelpfish Myxodes viridis in 6 stages of early development described: Newly hatched larva (A), 4.9 mm SL; preflexion larva (B), $5.11 \mathrm{~mm} \mathrm{SL}$; flexion larva (C), $7.03 \mathrm{~mm}$ SL; early postflexion larva (D), $8.71 \mathrm{~mm}$ SL; late postflexion larva (E), $9.44 \mathrm{~mm} \mathrm{SL;} \mathrm{Juvenile}$ (F), 27.3 mm SL. Drawings by F. Zavala-Muñoz. 


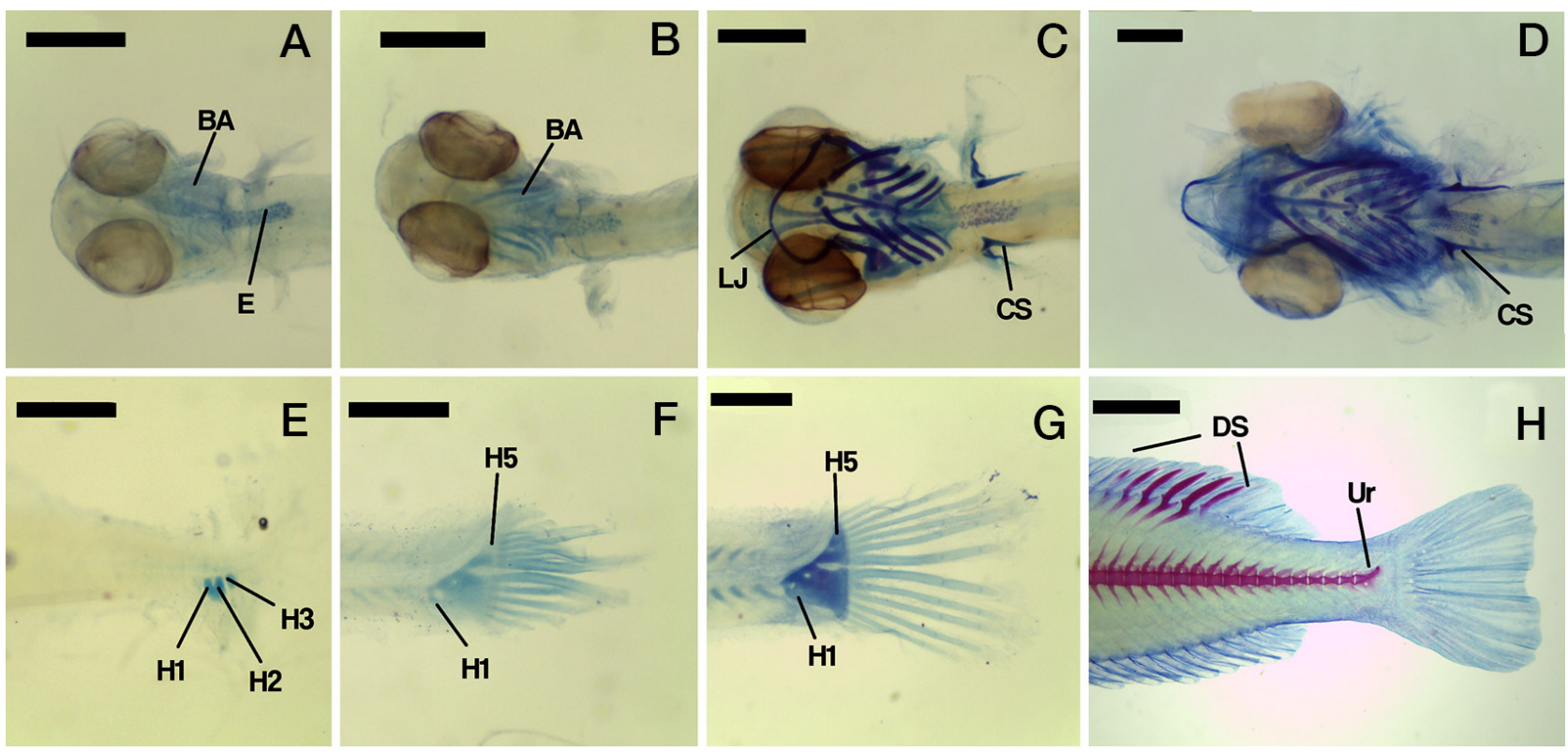

Fig. 3. - Cartilaginous and bony structures of heads (ventral view) and tails (lateral view) of M. viridis larvae. Images A, B, C and D show details of the progressive formation of cartilage in the gill arches of two preflexion, one flexion and one postflexion larvae, respectively. Images $\mathrm{E}, \mathrm{F}, \mathrm{G}$ and $\mathrm{H}$ show the formation of cartilage and bone in the tails of early flexion, late flexion, postflexion larvae and a juvenile individual, respectively. BA, branchial arches; E, esophagus; LJ, lower jaw; CS, coracoscapular cartilage; H, hyphurals; DS, Dorsal Spines; Ur, Urostyle. Scale bars, A, B, C, D, F and $\mathrm{G}=0.5 \mathrm{~mm}, \mathrm{H}=2 \mathrm{~mm}$.

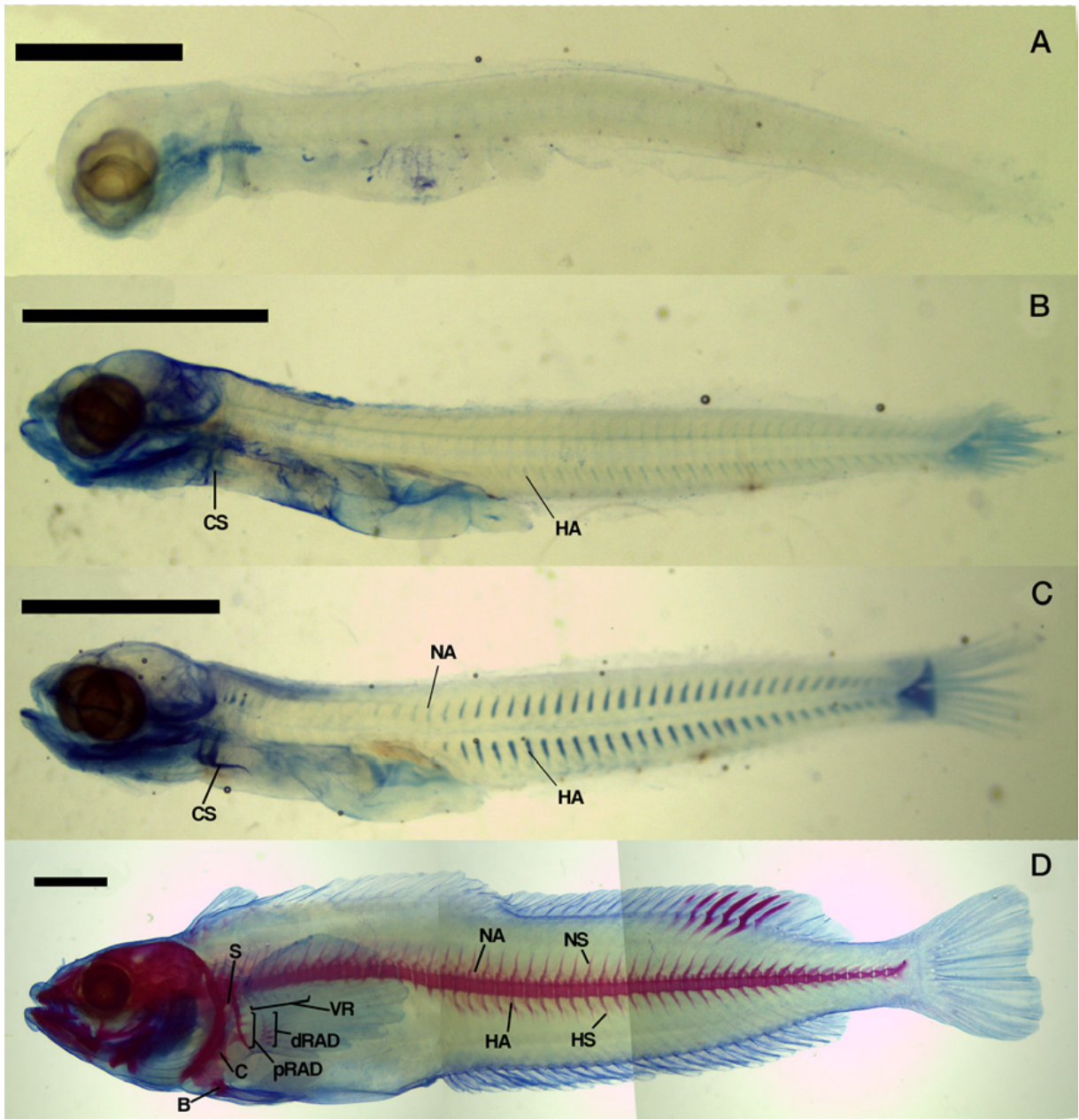

Fig. 4. - General view of cartilaginous and bony structures of 4 M. viridis individuals: Preflexion larva (A), 4.69 mm SL; late flexion larva (B), $7.17 \mathrm{~mm}$ SL; postflexion larva (C), $9.12 \mathrm{~mm}$ SL, Juvenile (D), $23.09 \mathrm{~mm}$ SL. CS, coracoscapular cartilage; HA, haemal arches; NA, neural arches; S, scapula; C, coracoid; pRAD, proximal radial bones; dRAD, distal radial bones; VR, ventral ribs; NS, neural spines; HS, haemal spines. Scale bars: $\mathrm{A}=1 \mathrm{~mm} ; \mathrm{B}, \mathrm{C}$ and $\mathrm{D}=2 \mathrm{~mm}$. 

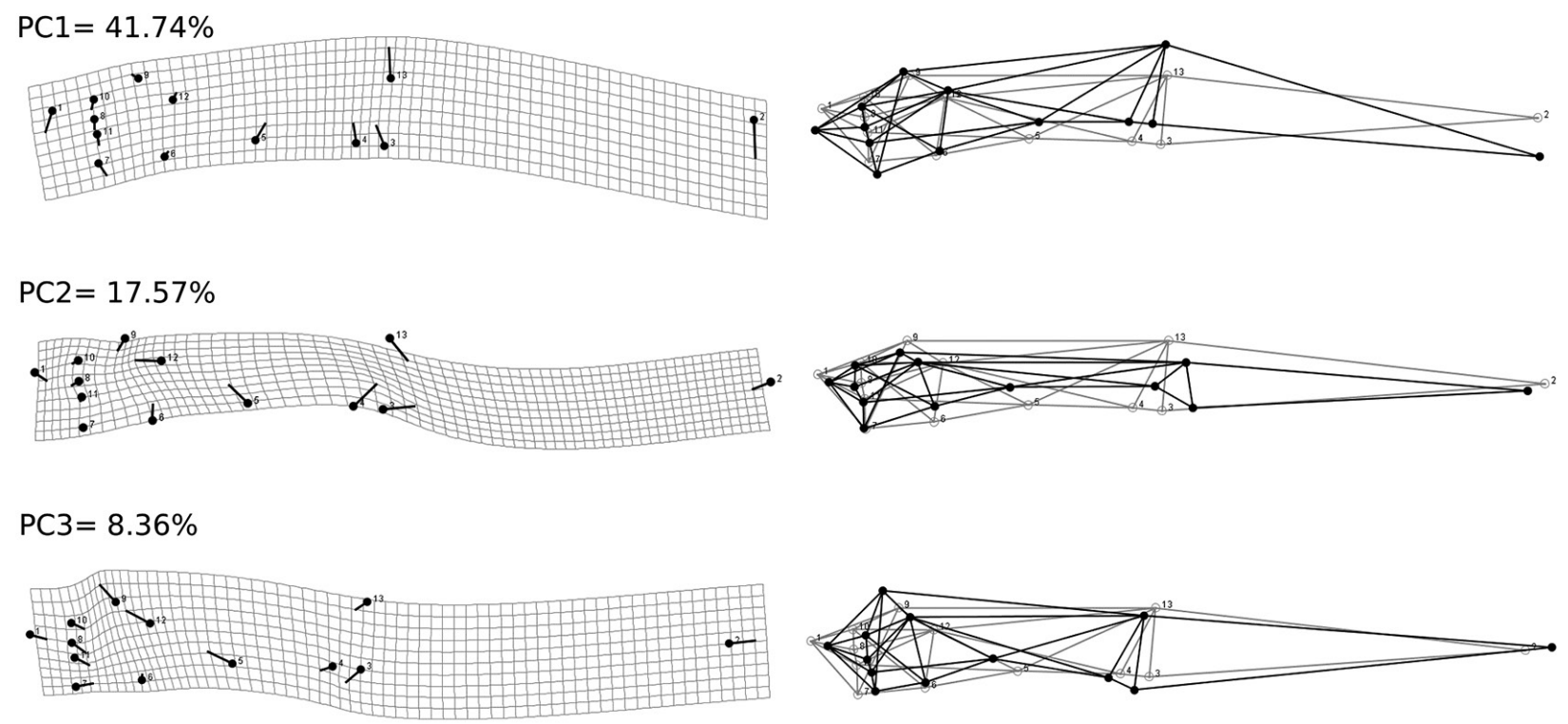

Fig. 5. - Transformation grids and wireframes representing the PCA shape changes associated with PC1, PC2 and PC3, showing changes for the relative position of each landmark. The grey outline represents the position of landmarks of the consensus, and the black outline represents landmark configurations.

\section{Chondrogenesis and ossification of larval kelpfish}

The double staining technique showed positive results in seven stained larvae. In preflexion larvae, only the six pairs of branchial arches and part of the esophagus were stained in a light blue colour. In flexion and postflexion larvae, these same structures, along with the lower jaw, showed a darker blue colour (Fig. 3AD). Flexion larvae showed the first signs of cartilaginous matrix in the forming hypural plates of the caudal fin. The sequence of formation started with hypural plates 1, 2 and 3 (Fig. 3E). In late flexion and postflexion larvae, it was possible to observe all five hypurals completely formed and stained dark blue, showing that these structures are solely formed by cartilage (Fig. 3F, G) Parahypurals and epurals were not stained and not distinguishable. In the juvenile individual, hypurals were not stained, and the urostyle is the only observable caudal structure in a strong pink tone (just like the last six spines of the dorsal fin), which indicates formed bony structures (Fig. $3 \mathrm{H}$ ).

First signs of chondrogenesis in the vertebral column were the haemal arches from the 17th vertebra (Fig. 4B). In postflexion larva (Fig. 4C) it is possible to observe all neural and vertebral arches, formed by cartilaginous tissue. There were no observable signs of chondrogenesis in vertebrae of preflexion, flexion or postflexion larvae (Fig. 4A-C). Only the juvenile individual showed completely ossified vertebral centra and neural and haemal arches, whilst neural and haemal spines were halfway formed and ventral ribs were barely visible (Fig. 4D).

Coracoscapular cartilage is visible in late flexion and postflexion larvae, at the base of the pectoral fin (Fig. 3c-d). In the juvenile individual, this same structure has ossified and divided into scapula and coracoid bones, which form a base for the proximal radial bones (also completely ossified). Distal radial bones closer to the ventral side of the body show some degree of ossification. In this same individual, the basipterygium bones, that give base to the pelvic fin, can be observed (Fig. 4D).

\section{Geometric morphometrics}

Variability of the Principal Component 1 ( $\mathrm{PC}=41.74 \%$, Fig. 5) is explained mainly by early ontogenetic changes in the vertical axis of the body, caused by a vertical compression in the abdominal area and a bending downwards of both extremes of the body (tip of the snout and posterior extreme of the tail). This main change in shape may be attributable to ontogenetic enlargement of shape as well as the effects of fixatives (formaldehyde, ethanol). Variability in PC2 $(17.57 \%)$ is explained by changes in the longitudinal axis of the body, triggered mainly by the elongation of the gut, and shortening of the head produced by a decrease in the distance between the tip of the snout and the opercle (Fig. 5). Finally, PC3 (8.36\% of the variation of shape) accounts for an increase in the head height, a shortening of the mandible and a deepening of the body height at the level of the anus (Fig. 5).

The variance unexplained by individual effect in the Procrustes ANOVA is the measurement error, corresponding to $1.96 \%$ (Table 2). The regression of Procrustes coordinates and centroid size (Fig. 6) estimates an ontogenetic allometry of $14.69 \%$. The permutation test against the null hypothesis of independence gives a $P$ value of 0.0001 .

Table 2. - Main results of the Procrustes ANOVA between individuals as main factor and replica as measurement error.

\begin{tabular}{lccccc}
\hline Effect & SS & MS & df & F & P \\
\hline Individual & 0.177 & $5.36 \times 10^{-4}$ & 330 & 61.25 & $<0.0001$ \\
Error (Replica) & 0.003 & $8.75 \times 10^{-6}$ & 352 & & \\
\hline
\end{tabular}




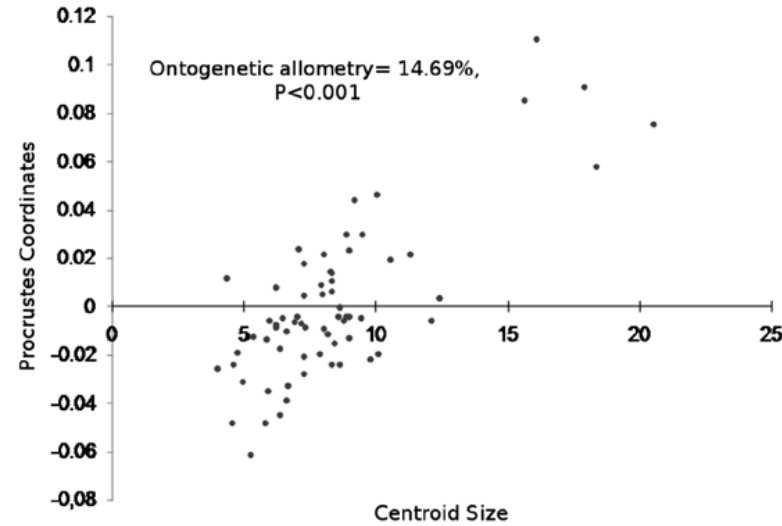

Fig. 6. - Regression of the Procrustes coordinates and centroid size for estimation of ontogenetic allometry during larval development of Myxodes viridis.

According to these results, body shape changes smoothly, in a continuous gradient throughout the larval development of Myxodes viridis. Major changes were expressed in the head and snout and, to a lesser extent, in the body height and shortening of the gut.

\section{DISCUSSION}

Preflexion larval kelpfish Myxodes viridis are likely to be confused with other co-occurring fish larvae in the coastal area of the southeastern Pacific Ocean, such as gobiid Ophiogobius jenynsi, triplefin Helcogrammoides chilensis and H. cunninghami, sand stargazer Sindoscopus australis, and several labrisomid species of the genera Auchenionchus, Calliclinus and Labrisomus (Ciechomski 1975, Hastings and Springer 2009, Herrera et al. 2007) (Table 3). The presence of a large ventral branched melanophore in the middle of the tail is a good character to distinguish preflexion and flexion larvae of $M$. viridis from the larvae of most of the other species. The larvae of two species also have a rather similar feature, the gobiid $O$. jenynsi and the labrisomid $A$. crinitus. The larvae of $O$. jenynsi have conspicuous melanophores along the ventral margin of the tail (Herrera 1984); however, these differ in the extension and branching pattern from those of $M$. viridis. Additionally, the larvae of $O$. jenynsi have a longer PAL $(>55 \%)$. The larvae of $A$. crinitus can be distinguished from those of $M$. viridis by having a smaller PAL, lower myomere numbers $(13+29-30$ vs. 16-18+31-34), more pectoral rays numbers (13 vs. 11 ), and two prominent stellate melanophores over the head that are absent in larval $M$. viridis (Landaeta, unpublished data). The postflexion larvae of other cooccurring Blenniioid species seem rather similar to $M$. viridis, but they can be easily identified based on a shorter PAL, 27-31\% SL in Sindoscopus australis (Herrera et al. 2007), and 30-38\% SL in Helcogrammoides chilensis (Pérez 1979).

Within the suborder Blennioidei, larvae are unspecialized and show few adaptations, morphology or pigmentation for pelagic life (Herrera and Lavenberg 1999), except for the presence of a gas bladder, absent in adult stages. The family Clinidae has been recog- nized as a natural group (Stepien et al. 1997, Lin 2009) that is related to Labrisomidae, Chaenopsidae and Dactyloscopidae. Relationships among the latter two are not fully resolved (Lin 2009, Betancur et al. 2013). The larvae of Clinidae, Labrisomidae, Chaenopsidae and Dactyloscopidae have elongated and relatively compressed bodies throughout the early stages, a rounded and comparatively small head, and short snouts. A common feature observed in the known larvae of the families is the presence of a pair of melanophores that develop below the pectoral fins in yolk sac larvae, at the level of the liver. The fate of these varies, as they become elongate in chaenopsids and fuse in the ventral midline under the basipterygium (e.g. Okiyama 1988, Brogan 1992, Herrera and Lavenberg 2002). Adittionally, clinids can be distinguished by a longer preanal length (clinids, $>45 \%$ SL; labrisomids, 35-44\% SL) (Watson 1996).

Among the Blennioidei, larvae are unspecialized and show few adaptations, morphology or pigmentation for pelagic life (Herrera and Lavenberg 1999). A common feature of the larvae of the three abovementioned families is the presence of a midlateral melanophore under the pectoral fin base, which moves ventrad and cephalad to near the ventral midline during development.

Both clinid and labrisomid larvae, throughout the early stages, have elongated and relatively laterally compressed bodies, with rounded and comparatively small head and snout length, although clinids can be distinguished for a longer preanal length (clinids: $>45 \%$ SL; labrisomids: 35-44\%SL) (Watson 1996).

The larvae of $M$. viridis show unusual developmental features within the Clinidae, and the Blennioidei. The pelvic fin develops at a comparatively larger size, as they were not observed in larvae $(<16 \mathrm{~mm})$ but only in juveniles $(>20 \mathrm{~mm})$. Furthermore, the dorsal and anal fin rays appear at larger sizes. In $M$. viridis, they form after $9.5 \mathrm{~mm} \mathrm{SL}$, whereas in other Blennoidei they are usually formed at smaller sizes (e.g. Watson 1996, Herrera and Lavenberg 2002).

It is assumed that larvae of $M$. viridis start their ossification process after hatching, since the smallest observed larva (4.69 $\mathrm{mm}$ SL) only showed faint signs of cartilage formation on the gill arches. Skull structures in general are the first to develop, since they sustain structures that are critical for feeding, respiratory and neurological functions (Koumoundouros et al. 2001). The early formation of cartilage in the coracoscapular bone may suggest that the pectoral fin fold provides stability or some degree of directionality in the trajectory of the larvae in the water column (Ott et al. 2009).

Larval duration for Myxodes viridis was recently estimated based on transition marks in the otolith, and ranged from 69 to 118 days (Mansur et al. 2014). The giant kelpfish Heterostichus rostratus has a pelagic larval duration (PLD) of around two months (Stepien 1986). Other species from temperate rocky reefs of central Chile have a PLD of two to four months (Plaza et al. 2013).

The effects induced on fishes by fixation and preservation vary among species (Tucker and Ches- 
ter 1984, Sagnes 1997) and influence the results of geometric morphometric analysis of adult (Martínez et al. 2013) as well as larval stages (Nikolakakis et al. 2014). The samples utilized for geometric morphometrics in this study were initially fixed in formaldehyde and transferred to $96 \%$ ethanol after $12 \mathrm{~h}$. The major changes in the shape of $M$. viridis during the larval development were focused mainly in the head, in addition to a shortening in the preanal length. These changes, particularly the bending of the extremes of the body, may be due to formalin-ethanol fixatives (C.P. Klingenberg, pers. comm.). Although this methodology has few effect on fish larvae shape (Nikolakakis et al. 2014), it is important to carry out new studies about the effects of fixatives in larval fish shape, and/or to study the shape change with anaesthetized larvae and juveniles.

Also, the shape changes coincided with variations in the diet of larvae from preflexion to postflexion (change from omnivory to exclusive carnivory, OchoaMuñoz et al. 2013), and may be considered as a preparation for adult feeding tactics in a benthic habitat. Adults use their pointed head to search and capture prey under rocks and boulders (Landaeta, pers. obs.). Also, the subtle changes in the body shape throughout larval development, with a slow development of the tail and caudal rays, suggest that the ability to swim early in life is not well developed for Myxodes (Fuiman 1983). The Fuiman method for estimating growth gradients in fish larvae uses the eye diameter as standard, so it does not consider the whole shape of the larvae in order to calculate the allometric growth. Although the allometry is classically estimated from a power func- 
tion (Huxley 1932), in geometric morphometry the allometry is better explained by a regression between Procrustes coordinates and centroid size (Klingenberg and Marugán-Lobón 2013).

Similarly, the blenniid Ecsenius strictus show slow critical swimming speeds (U-critic, $5.5 \pm 2.2 \mathrm{~cm} \mathrm{~s}^{-1}$ ) compared with those of other coral reef larvae $(>30$ $\mathrm{cm} \mathrm{s}^{-1}$, Fisher et al. 2005). Additionally, allometric growth, estimated by the regression of the Procrustes coordinates and centroid size, accounted for a small portion of the shape change (less than $15 \%$ of variation). This finding suggests that the final shape (juvenile) is reached early in the development, and most changes occur during the preflexion and flexion stages. Therefore, we conclude that early shape changes during the development of the kelpfish Myxodes viridis are aimed at an increase in feeding success (because of the modifications in the head shape) and probably an increase in the digestion capabilities (due to a shortening of the gut when larvae are mostly carnivorous), rather than an increase in predator avoidance (through the development of the tail and caudal bones).

\section{ACKNOWLEDGEMENTS}

We appreciate the help and comments of Prof. Fernando Balbontín (Universidad de Valparaíso). Also, we thank Dr. C.P. Klingenberg (University of Manchester) for comments and suggestions, during the course "Integration and Modularity with Geometric Morphometrics", organized by Transmitting Science. Comment of two reviewers improved an early version of the manuscript. This study was partially funded by the grants of the projects Fondecyt 1100424 to Dr. F. Patricio Ojeda (Pontificia Universidad Católica de Chile), Fondecyt 1120868 to Dr. Gabriela Muñoz (Universidad de Valparaíso) and INACH RT_04-13 to MFL.

\section{REFERENCES}

Ahlstrom E.H., Ball O.P 1954 Description of eggs and larvae of jack mackerel (Trachurus symmetricus) and distribution and abundance of larvae in 1950 and 1951. Fish. Bull. U.S. 52: 209-245.

Ahlstrom E.H., Moser H.G., O'Toole M.J. 1976. Development and distribution of larvae and early juveniles of the commercial lanternfish, Lampanyctodes hectoris (Günther) off the west coast of southern Africa with a discussion of phylogenetic relationships of the genus. Bull. South. Cal. Acad. Sci. 75: 138-152.

Balbontín F., Pérez R. 1979. Modalidad de postura, huevos y estados larvales de Hypsoblennius sordidus (Bennett) en la Bahía de Valparaíso (Blenniidae: Perciformes). Rev. Biol. Mar. 16: 311-318.

Betancur-R.R., Broughton R.E., Wiley E.O., et al. 2013. The Tree of Life and a new classification of bony fishes. PLoS Curr. 18: 5 . http://dx.doi.org/10.1371/currents.tol.53ba26640df0ccaee75bb $165 \mathrm{c} 8 \mathrm{c} 26288$

Bookstein F. 1991. Morphometric tools for landmark data. Geometry and Biology. Cambridge Univ. Press, $455 \mathrm{p}$.

Brogan M. 1992. Ecology of larval fishes around reefs in the Gulf of California, México. PhD. thesis, Univ. Arizona, $161 \mathrm{p}$.

Castillo R.M., Pequeño G. 1998. Sinopsis de Tripterygiidae de Chile (Osteichthyes: Perciformes). Gayana Zool. 62: 109-133.

Ciechomski J. 1975. Características y distribución de post-larvas del acorazado Agonopsis chiloensis (Jenyns, 1842) Jordan y Evermann, 1898, y de Tripterygion cunninghami Smitt, 1898 en aguas del Atlántico frente a la Argentina (Pisces). Physis A 84: 309-317.
Fisher R., Leis J.M., Clark D.L., et al. 2005. Critical swimming speeds of late-stage coral reef fish larvae: variation within species, among species and between locations. Mar. Biol. 147: 1201-1212. http://dx.doi.org/10.1007/s00227-005-0001-x

Frédérich B., Adriaens D., Vandewalle P. 2008. Ontogenetic shape changes in Pomacentridae (Teleostei, Perciformes) and their relationships with feeding strategies: a geometric morphometric approach. Biol. J. Linn. Soc. 95: 92-105. http://dx.doi.org/10.1111/j.1095-8312.2008.01003.x

Frédérich B., Colleye O., Lepoint G., et al. 2012. Mismatch between shape changes and ecological shifts during the postsettlement growth of the surgeonfish, Acanthurus triostegus. Front. Zool. 9: 8 . http://dx.doi.org/10.1186/1742-9994-9-8

Fuiman L. 1983. Growth gradients in fish larvae. J. Fish Biol. 23: 117-123. http://dx.doi.org/10.1111/j.1095-8649.1983.tb02886.x

George A., Springer V. 1980. Revision of the clinid fish tribe Ophiclinini, including five new species, and definition the family Clinidae. Smithson. Contrib. Zool. 307: 1-30. http://dx.doi.org/10.5479/si.00810282.307

Gillis G., Randall D., Shubin N. 2009. Chondrogenesis and homology of the visceral skeleton in the little skate, Leucoraja erinacea (Chondrichthyes: Batoidea). J. Morph. 270: 628-643. http://dx.doi.org/10.1002/jmor.10710

Hastings P., Springer V. 2009. Systematics of the Blennioidei and the included families Chaenopsidae, Clinidae, Labrisomidae and Dactyloscopidae. In: Patzner R., Goncalves E., Hastings P., et al. (eds), The Biology of Blennies. Enfield, NH. Science Publishers, pp. 3-30. http://dx.doi.org/10.1201/b10301-3

Herrera G. 1984. Descripción de estados post-embrionales de Ophiogobius jenynsi Hoese 1976 (Gobiidae, Blenniioidei). Rev. Biol. Mar. 20: 159-168.

Herrera G.A. Lavenberg R.J. 1999. Larval Labrisomidae (Pisces: Blennioidei) from the Galápagos Islands. Contrib. Sci. 48: 1-14.

Herrera G.A., Lavenberg R.J. 2002. Larval blennies from the Galapagos and Cocos Islands: families Tripterygiidae, Dactyloscopidae, and Chaenopsidae (Perciformes, Blennioidei). Contrib. Sci. 488: 1-15.

Herrera G., Llanos-Rivera A., Landaeta M.F. 2007. Larvae of the sand stargazer Sindoscopus australis and notes on the development of Dactyloscopidae (Percifomes: Blennioidei). Zootaxa 1401: 63-68.

Huxley J.S. 1932. Problems of Relative Growth. London: Methuen and Co. $312 \mathrm{p}$.

Klingenberg C. 2011. MorphoJ: an integrated software package for geometric morphometrics. Mol. Ecol. Resour. 11: 353-357. http//dx.doi.org/10.1111/j.1755-0998.2010.02924.x

Klingenberg C. 2013. Visualizations in geometric morphometrics: how to read and how to make graphs showing shape changes. Hystrix 24: 15-24.

Klingenberg C., Monteiro L. 2005. Distances and directions in multidimensional shape spaces: implications for morphometric applications. Syst. Biol. 54: 678-688. http://dx.doi.org/10.1080/10635150590947258

Klingenberg C., Marugán-Lobón J. 2013. Evolutionary covariation in geometric morphometric data: Analyzing integration, modularity, and allometry in a phylogenetic context. Syst. Biol. 62: 591-610. http://dx.doi.org/10.1093/sysbio/syt025

Koumoundouros G., Divanach P., Kentouri M. 2001. Osteological development of Dentex dentex (Osteichthyes, Sparidae): dorsal, anal, paired fins and squamation. Mar. Biol. 138: 399-406. http://dx.doi.org/10.1007/s002270000460

Kouttouki S., Georgakopoulou E., Kaspiris P., et al. 2006. Shape ontogeny and variation in the sharpsnout seabream, Diplodus puntazzo (Cetti 1777). Aqua. Res. 37: 655-663. http://dx.doi.org/10.1111/j.1365-2109.2006.01475.x

Lin H. 2009. Evolution of the suborder Blennioidei: phylogeny and phylogeography of a shallow water fish clade. Ph.D. thesis, Univ. California, San Diego, 150 pp.

Lleonart J., Salat J., Torres G.J. 2000. Removing allometric effects of body size in morphometrical analysis. J. Theor. Biol. 205: 85-93. http://dx.doi.org/10.1006/jtbi.2000.2043

Loy A., Mariani L., Bertelletti M., et al. 1998. Visualizing allometry: geometric morphometrics in the study of shape changes in the early stages of the two-banded sea bream, Diplodus vulgaris 
(Perciformes, Sparidae). J. Morphol. 237: 137-146 h t t p://dx.doi.org/ $10.1002 /$ ( S I C I ) 1097 4687(199808)237:2<137::AID-JMOR5>3.0.CO;2-Z

Mansur L., Plaza G., Landaeta M., et al. 2014. Planktonic duration in fourteen species of intertidal rocky fishes from the southeastern Pacific Ocean. Mar. Freshw. Res. 65: 901-909. http://dx.doi.org/10.1071/MF13064

Martínez P., Berbel-Filho W., Jacobina U. 2013. Is formalin fixation and ethanol preservation able to influence in geometric morphometric analysis? Fishes as a case of study. Zoomorphology 132: 87-93. http://dx.doi.org/10.1007/s00435-012-0176-x

Menegola E., Broccia M., Giavini E. 2001. Atlas of rat fetal skeleton double stained for bone and cartilage. Teratology 64: 125-133. http://dx.doi.org/10.1002/tera.1055

Mitteroecker P., Gunz P., Bernhard M., et al. 2004. Comparison of cranial ontogenetic trajectories among great apes and humans. J. Hum. Evol. 46: 679-698. http://dx.doi.org/10.1016/j.jhevol.2004.03.006

Moser H. 1996. Introduction. In: Moser H (ed.), The early stages of fishes in the California Current region, pp. 1-72. Kansas City, KS: Allen Press.

Neira F., Miskiewicz A., Trnski T. 1998. Larvae of Temperate Australian Fishes. Laboratory guide for larval fish identification. Univ. Western Australia Press, Nedlands, 474 pp.

Nikolakakis S., Bossier P., Kanlis G., et al. 2014. Protocol for quantitative shape analysis of deformities in early larval European seabass Dicentrarchus labrax. J. Fish. Biol. 84: 206-224. http://dx.doi.org/10.1111/jfb. 12284

Ochoa-Muñoz M., Valenzuela C., Toledo S., et al. 2013. Feeding of a larval clinid fish in a microtidal estuary from southern Chile. Rev. Biol. Mar. Oceanogr. 48: 45-57. http://dx.doi.org/10.4067/S0718-19572013000100005

Okiyama M. 1988. An atlas of the early stage fishes in Japan. Tokai Univ. Press, Tokio. 1154 pp.

Ott A., Löffler J., Ahnelt H., et al. 2009. Early development of the postcranial skeleton of the Pikeperch Sander lucioperca (Teleostei: Percidae) relating to developmental stages and growth. J. Morph. 273: 894-908 http://dx.doi.org/10.1002/jmor.20029

Pequeño G., Lamilla J., Lloris D., et al. 1995. Comparación entre las ictiofaunas intermareales de los extremos austral y boreal de los canales patagónicos. Rev. Biol. Mar. 30(2): 155-177.

Pérez R. 1979. Desarrollo postembrionario de Tripterygion chilensis Cancino 1955, en la Bahía de Valparaíso (Tripterygiidae: Perciformes). Rev. Biol. Mar. 16: 319-329.

Plaza G., Landaeta M., Espinoza C., et al. 2013. Daily growth patterns of six species of young-of-the-year of Chilean intertidal fishes. J. Mar. Biol. Ass. UK 93: 389-395. http://dx.doi.org/10.1017/S0025315412000859

Rohlf F. 2006. TpsDig Ver. 2.10, Digitalized Landmarks and Out- lines. Department of Ecology and Evolution, State Univ. New York: Stony Book.

Russo T., Costa C., Cataudella S. 2007. Correspondence between shape and feeding habit changes throughout ontogeny of gilthead sea bream Sparus aurata L., 1758. J. Fish. Biol. 71: 629-656. http://dx.doi.org/10.1111/j.1095-8649.2007.01528.x

Russo T., Pulcini D., Bruner E., et al. 2009. Shape and size variation: growth and development of the dusky grouper (Epinephelus marginatus Lowe, 1834). J. Morph. 270: 83-96. http://dx.doi.org/10.1002/jmor.10674

Sagnes P. 1997. Potential artefacts in morphometric analyses of fish: effects of formalin preservation on $0+$ grayling. J. Fish. Biol. 50: 910-914 http://dx.doi.org/10.1111/j.1095-8649.1997.tb01986.x

Sidlaukas B.L., Mol J.H., Vari R.P. 2011. Dealing with allometry in linear and geometric morphometrics: a taxonomic case study in the Leporinus cylindriformis group (Characiformes: Anostomidae) with description of a new species from Suriname. Zool. J. Linn. Soc. 162: 103-130. http://dx.doi.org/10.1111/j.1096-3642.2010.00677.x

Stephens J., Springer V. 1973. Clinid fishes of Chile and Peru, with description of a new species, Myxodes ornatus from Chile. Smithson. Contrib. Zool. 159: 1-24. http://dx.doi.org/10.5479/si.00810282.159

Stepien C. 1986. Life history and larval development of the giant kelpfish, Heterostichus rostratus Girard, 1854. Fish. Bull. 84(4): 809-826.

Stepien C. 1990. Population structure, diets and biogeographic relationships of a rocky intertidal fish assemblage in central Chile: high levels of herbivory in a temperate system. Bull. Mar. Sci. 47: 598-612.

Stepien C. 1992. Evolution and biogeography of the Clinidae (Teleostei: Blennioidei). Copeia 1992(2): 375-392. http://dx.doi.org/10.2307/1446198

Stepien C., Dillon A., Brooks M., et al. 1997. The Evolution of Blennioid Fishes Based on an Analysis of Mitochondrial 12S rDNA In: Kocher T., Stepien C. (ed.) Molecular Systematics of Fishes, Academic Press, London, pp. 245-270. http://dx.doi.org/10.1016/B978-012417540-2/50016-6

Tucker J., Chester A.J. 1984. Effects of salinity, formalin concentration and buffer on quality of preservation of southern flounder (Paralichthys lethostigma) larvae. Copeia 1984: 981-988. http://dx.doi.org/10.2307/1445343

Watson W. 1996. Clinidae. In: Moser H (ed.) The Early Stages of Fishes in the California Current Region. Atlas $\mathrm{N}^{\circ} 33$. California Cooperative Oceanic Fisheries Investigations, Allen Press Inc., Kansas, USA, pp. 1164-1169.

Zeldrich M., Swiderki D., Sheets H., et al. 2004. Geometric Morphometrics for Biologists: A Primer. San Diego, CA, Academic Press. 